TURIZAM

Volume 15 , Issue 1

26-39 (2011)

\title{
Actuation and Promotion Mechanisms of Urban Tourism: The Case of Seville (Spain)
}

\author{
Roberto Diez Pisonero* \\ Received: ???? 2010| Accepted: ???? 2010
}

\section{Abstract}

Tourist activity in Seville right now constitutes one of the fundamental pillars of the economic, social and cultural progress of the city. Seville's importance lies not only in its plentiful monumental and artistic heritage, but also in the rest of the characteristics of the city that come together to form the tourist product (infrastructure, accommodation, catering, shops, recreational areas...).

Its diversified offerings in other areas such as business, shopping, gastronomy and golf, in addition to its excellent position in the world tourist system as well as its image as a tourist destination and its international projection, have turned Seville, the Andalusian capital, into one of the biggest tourist metropolis in the south of Europe.

This paper attempts to provide a better understanding of the phenomenon and the complexity of urban tourism using a successful case as an example. To that effect, using a methodology based on the compilation, filtration and proper organization of information, it presents an analysis of the actions different administrations have taken to better the positioning of Seville in the global tourism industry.

The analysis focuses on two aspects of the rise of Seville as a successful tourist attraction: the first, the different strategies employed to refine the tourist product, promotion, commercialization, planning, marketing, quality and sustainability; and second, the strengthening of the transport infrastructure that added dynamism to this Spanish city. Through this analysis, the paper complements existing literature on the topic by adding to our knowledge of the tourist industry.

Keywords: Urban and sustainable tourism, strategic planning, promotion mechanisms, transport infrastructures, Seville (Spain).

* Department of Regional Analysis in Geography, Complutense University of Madrid, Spain, e-mail: roberto1opisonero@hotmail.com 


\section{Introduction}

Tourism has been conceptualised in many different ways within the discipline of social science. In contemporary society, tourism represents through its content and role, "a distinctive domain of activity, an essential component of the economical and social life for a growing number of world countries, countries that see in their own touring potential a real wealth generator" (Popescu and Corbus, 2OIO).

Tourism is considered first of all a "recreation form besides other activities and formulas of spending the leisure time" (Holloway, I994). According to this author, tourism is a "complex activity, with a multitude of fronts, with significant economical loading, positioned at the intersection of more branches and sectors of economy; all these find their reflection in the variety of points of view regarding the content of tourism concept and the adjacent concepts" (Holloway, I994).

The global world in which we are inserted has greatly facilitated the movement of the people and, consequently, of tourists who see now, better than never, the possibility of being able to discover the idiosyncrasy and specificity of the cities that populate the world. That is, here, there, everywhere, tourism is a well-established urban reality.

Today, urban tourism has become a decisive factor in the rebirth of cities. Therefore, urban developments, patrimonial, architectural and functional recovery of urban entities have become the focal point of many development efforts. That is why it is said that urban tourism, if correctly planned, developed and managed, "may create advantages and benefits both to urban communities and overall society" (Iordache and Cebuc, 2009). In others words, tourism, in general, but especially the urban kind, constitutes an important backbone and a revitalizing tool of our cities.

The most recent trends and forecasting studies by the World Trade Organization (WTO) indicate that cities will continue to be in high demand by tourists of all sorts, and the problems associated with the handling of these tourists will have to be more systematically tackled by all parties concerned.

Therefore, cities face a double challenge, described by the Conference on "Tourism and the City: The challenge of Sustainability" as: Firstly, they have to be able to respond to the expectations and needs of the growing number of tourists who are attracted to their rich and varied array of cultural, business, entertainment, shopping, sports and other attractions; furthermore, they need to continuously renovate and improve such facilities in order to maintain their share in the competitive tourism market and the benefits resulting from it.

Secondly, cities have to ensure that tourism is developed and managed in such a way that it benefits the resident population, does not contribute to the deterioration of the urban environment but rather to its enhancement, and does not become a financial burden to the local authority" (Conference on "Tourism and the City: The challenge of Sustainability" Madrid, I999).

In this reality, the different Spanish Administrations play a crucial role since with the State of the Autonomies, tourist matters are decentralized thus allowing the Autonomous Communities and other administrative states to adopt responsibilities related to tourism.

Precisely, it is in these moments when the Autonomous Spanish Communities are executing an important strategic planning of tourism with the aim of increasing the number of tourists, the duration of their stay and the total amount of money spent. At the same time, the Communities are promoting only those touristic experiences that will result in repeated visits to the city. 
For this reason, in a tourist city, while cultural heritage is an important part of the product offered to tourists it cannot be the only one. As Moragas has indicated, "selling the past in its different forms is one of the principal claims of tourist marketing" (Romero Moragas, 2004). Nevertheless, as we will see later, an important current idea is to consciously "place a value" on all this material and immaterial patrimony.

It is within this dynamic context that the following sections address the actions and promotional mechanisms undertaken by several administrations to better position Seville within the tourist industry.

\section{What the Tourism in Seville Means}

The tourist activity in Seville constitutes at present, without any doubt, one of the fundamental pillars of the economic, social and cultural progress of the city, that is, a forceful reality which has a wide impaction any of the fields of civil life.

Its importance stems from not only the plentiful monumental and artistic heritage of the city, but also in the other aspects that make up the tourist product (infrastructures, housing, catering, trade, recreation areas ...).

Nowadays, tourism represents about II \% of the GDP in the economy of the city, which gives an idea of its enormous relevancy. However, its impact on the socio-economic situation of Seville is enormous given that the multi-directional relations so typical of this economic segment lead it to include many other sectors - either in a major or minor way- such as trade, transport, agricultural industries, construction, culture, craftwork and a wide set of services (Consortium Tourism Seville, 2008).

The excellent positioning of the city in the tourist world system as well as, the strategic importance of this segment in the economy and employment of Seville are a reality.

The spectacular growth registered in this sector takes place because of the tourist industry that represents Seville: alive, agile, competitive and with a clear projection of the future. Hence, many authors agree in affirming that we are in the presence of "one of the principal tourist destinations of the world" (Marchena and Repiso, I999).

Its competitiveness in the domestic and international markets is based on an image and on a name universally known and recognized for centuries by the singular character of its celebrations and heritage, which marks an authentic reference to many other cities that they try to accede to positions of privilege as the one that Seville enjoys.

On this solid base, over the last decade, a structure of the tourist product that is very effective and of high quality, in the services, in the housings and in the variety of the tourist offer has been constructed. But besides all this, "tourism has a transcendental incident in an intangible factor as important as it is the image of the city, its exterior projection and, as a result, its positioning in the world system of big cities" (Town Council Seville, 2006).

\section{Courses of Action in Tourist Matters}

Such is the importance of tourist activity for the city of Seville that the administration of the city has continued to invest in it. However, because of the drive to make Seville's tourism industry more competitive and the sustained focus on modernizing it, an ongoing adjustment process as a result of the increasing demand for tourism related services and infrastructure continues. 


\section{Diversification of the offer}

Seville owns an important tourist binomial: monumental heritage plus traditional culture. Two principal attractions identify the city: on the one hand, the cathedral, the Fortress, the Tower of the Gold, the palaces and buildings of government, its churches and basilicas; and on the other, the Holy Week, the Fair of April, the bullfighting, the flamenco, etc ... Nevertheless, the city has been able to adapt to the needs of the 2Ist century by diversifying its tourist offering as consumer interests evolve.

Business tourism. Integrated into the network of the Spanish Conventions Bureau, Seville offers the venues necessary to host major meetings and high-level conferences. Both the Exhibitions and Congresses Palace of the City and El Palenque, with 30,000 and 9,000 $\mathrm{m}^{2}$ respectively, each host more than one hundred congresses, exhibitions, fairs, symposiums and professional meetings, thus making Seville one of the principal destinations of business tourism in Spain (www.fibes.es).

Gastronomic tourism. The gastronomic tourism, in constant growth in Spain, also leaves its mark on the city of Seville. Without a doubt, Sevillian gastronomy is one of the richest in Spanish food, characterized by its variety and its quality. Sevillian gastronomy is defined by its famous "tapas," but also includes the Andalusian "gazpacho", the Sevillian "ensaladilla", Sevillian veal, and the "pringá". In Seville, eating is not only an act it is a cultural ritual.

The Association of Hotel and Catering Business, with the motto "Quality guarantee", undertakes the marketing of Sevillian restaurants and hotels in a continuous process of adjustment to new demands, the inclusion of new cultures, desires and needs of its clients. At every moment, these establishments offer the best culinary elaborations and ensure quality in the products and the food used, as well as perfect service and friendly treatment, all at very competitive prices (www.visitingsevilla.com/turismgastronomico).

Shopping tourism. Seville has turned into an important fashion centre in the past few years and boasts local tailors of the calibre of Victorio and Lucchino or Toni Benítez, as well as with important thematic institutions as the Andalusian Center of Fashion.

In addition, the city offers traditional establishments where tourists can buy anything from crafts and collectibles in local shops to sophisticated designer items in malls. The variety of establishments create an atmosphere of possibilities available to the visitor who can choose from a articles from Old Town, popular ceramics in Triana, the "bargains" of the street markets and the neighbourhood of the "Nervión", where the malls, duty-free shops, and the first signatures of fashion reside (www.turismodesevilla.org).

River tourism. Located 80 kilometres from the river mouth of the Guadalquivir, the port of Seville is the only fluvial commercial port that exists in Spain, with terminuses, moor and wharves all along the way, in the very heart of Seville, up until the terminus of cruises and sports ports. Its projection is simultaneously Mediterranean and Atlantic, a combination that makes it a very important logistical and commercial point.

The city of Seville and the Port of Seville complement each other. Because of the tourist attractions of Seville, the Port of Seville has turned into regular port-of-call for cruises that each year choose the Andalusian Capital as a preferential destination, either because of its maritime routes or as an entryway into the city. The boom of this activity and the development of the Pier/ Wharf with the new system of cruises further promote the integration of the Port in the City of Seville resulting in increases tourist activity (www.apsevilla.org).

Tourism of Golf. Seville is the place chosen by increasingly visitors to practise this tourist activity. The number and variety of the golfing facilities, the privileged climate and the reputation and prestige of its courses have turned Andalusia into a destination for first-class golf. 
In this context, Seville enjoys one of Europe's best courses, The Royal Club of Golf of Seville, headquarters of the World Cup 2004. Designed by Spanish golfer Jose Maria Olazábal, it presents a demanding tour very valued by professional players and amateurs. In addition, the Club has unsurpassed facilities that greatly enrich its sports opportunities and turn it into a suitable place for the enjoyment of family leisure. Also, its proximity to Oromana's Nature Reserve makes it very attractive as a complement to eco and cultural tourism (www.sevillagolf.com).

Idiomatic tourism (as a sub segment of cultural tourism). The Spanish language is a tourist resource with enormous potential. It is positioned as the second most used language of international communication and the fourth most often spoken around the world (Institute Cervantes, 2009). Hence, interest in Spanish as a second language continues to increase in numerous countries of the old and the new world. The importance of the Spanish language as a touristic resource and its enormous potential in Spain is already a reality as exemplified by the increasing number of students of Spanish, as well as the burgeoning offer of Spanish classes and schools.

Nevertheless, language tourists not only decide what course to study, but in which destination to do so. It is in this decision process that Sevillian culture plays a crucial role since many of these students decide to come to the city for the important material and immaterial legacy that exists inside the metropolis (Prados, 2OOI). In this sense, the synergies between the tourist and linguistic polities position Seville as one of the principal destinations in which to learn the language of Cervantes in Spain.

\section{Adequacy of the tourist product}

Tourist urban signposting. The town council, with the aim to facilitate walking around the city as well as to pinpoint the location of the principal tourist attractions of the city has decided to undertake actions to improve pedestrian tourist signposting with standardized directing panels with information in different languages.

Pedestrianization of the historical centre. Since the year 2003, the city has been partaking in these types of works in the streets bordering the downtown area. The aim is to minimize the impact of traffic in the tourist zone and to reinforce the role of the tourist.

Renovation of the Office of Attention to the Tourist and establishment of new Offices of Information throughout the whole city to address any incident that could arise: necessary information, defence of the tourist, etc. In addition, they have tried to change the orientation programs offered by these centres from simply an "information leaflet" to the inclusion of audio-visual technologies to permit the tourist to interpret Seville reality. Therefore, the offices were redesigned and the contents of orientation materials were improved.

Lighting enclave and monumental sets. For the adequacy and embellishment of the tourist product, the Town Council has developed measures for strategic lighting on and around the principal monumental elements. The aim is the praise/extolment and embellishment of the principal milestones during the Sevillian night.

Putting in value of resources and tourist routes. From the Town Council of Seville, the restoration of different tourist itineraries has been supported by the city for the accomplishment and development of the touristic practice. Among the most interesting, the following stand out: Triana, baroque Seville, mudejar Seville, Exposition of I927, Seville of the painters and Roman Seville. 

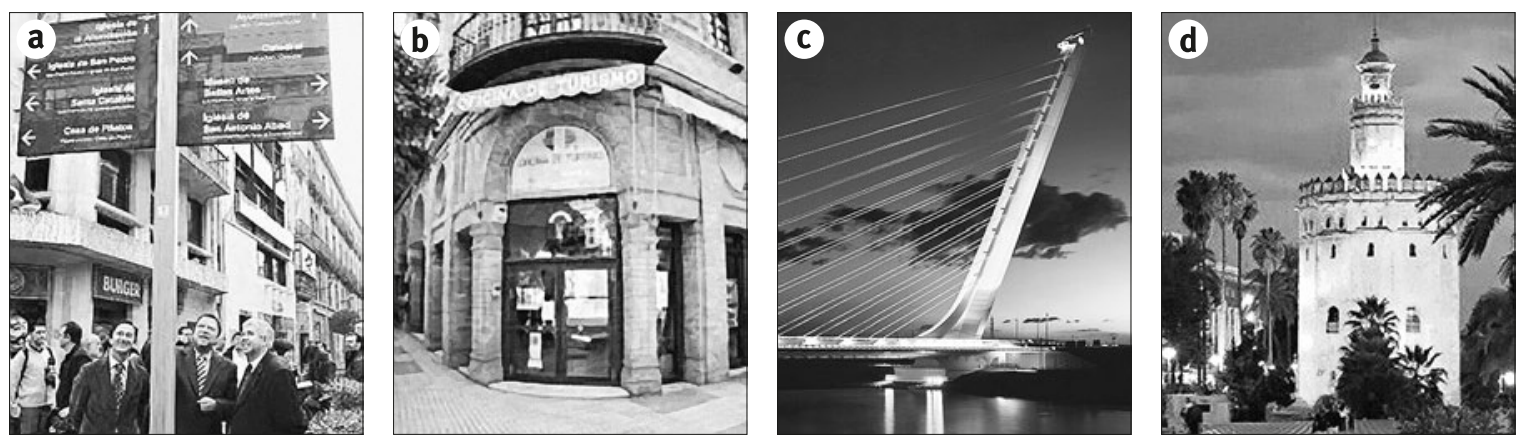

Figure 1 Adequacy of the tourist product

a) Tourist urban Signpostingg; b) Renovation Office of Attention to the Tourist; c) Vanguardist architecture Renowned architects; d) Lighting enclave and monumental sets

Source: Town Council of Seville

New cultural heritage on a symbolic and emblematic scale. In order to accentuate the uniqueness and identity of the city in the Spanish and European tourist context, the construction of one-of-a-kind buildings that identify the city had been commissioned to renowned architects, among them: Calatrava's ultramodern bridge or Rafael Moneo's new international airport. Likewise, in the year 2008, the works of a residential neighborhood were started thanks to the "galactic ones" of the current architecture, among them, the Frenchman Jean Nouvel, the British Norman Foster and the Japanese Arata Isozak.

\section{Creation of new products}

Apart from the different measures undertaken by the Town Council in search of the adequation of the touristic product, Seville has modernized and become more competitive through an offering of new products, among which stand out the following:

- Seville Card. A new municipal mechanism to stimulate tourist activity, this card allows the tourist to discover the city and to save money through benefits such as: free access to the majority of museums and monuments of the city, unlimited use of the public transportation, etc. (www.sevillacard.es).

- Channel for tourist information. It is a question of a platform of tourist television, similar to thematic television, whose format alone appears in the European cities of Glasgow and London. It broadcasts from the Internet and its website is www.turismosevilla.tv. On this channel, it is possible to view a complete gridiron of programming integrated by different tourist sections. According to its creators, it combines the "visual wealth" of television programming with the absence of "borders" and the "interaction" that the Internet provides, "being able to adapt the emission to every user".

\section{Development of joint programs (NETWORKS)}

The integration in networks constitutes a management instrument of increasing importance as well as an area for the generation of shared knowledge and an efficient route of international projection. Among others, Seville takes part in the following networks of cities, linked directly or indirectly to tourist activity: 
- Network of cities "Spain Convention Bureau". Their fundamental aim is to promote the exchange of experiences and information of the tourist sector among the municipalities that form the section as well as to realize actions directed at the joint national and international promotion of the cities that compose it (www.scb.es).

- Network of "cathedral cities". This is characterized by acting together in the promotion and defence of urban development, historical and cultural heritage of the municipalities that shape it, as well as to establish policies of exchanges to facilitate joint planning of image diffusion (www.ciudadescatedralicias.org).

- Network of "Cities of the Route of the Silver". This network is established on a traditional axis of communication of the Spanish west. It constitutes a rich and varied itinerary, which possesses several cities named as part of Heritage of Humanity and which represent the world-class cultural and tourist potential of the Iberian Peninsula and the European Union. It favors joint action in the defense and promotion of its touristic, historical, cultural and economical resources (www.rutadelaplata.com).

- Network of “cities AVE". It facilitates and propitiates fruitful collaboration for the development and touristic promotion of destinations integrated through the perspective of cities connected by high speed train. Its slogan: "Nine cities waiting to meet you. Follow a route constructed for the 2Ist century (that will carry you from Andalucía to Cataluña, passing through Castilla-La Mancha, Madrid and Aragón). Discover the variety, the taste and the excellence. Welcome to the AVE cities. Now we are closer to you" (www.redciudadesave.es).

- Network of "cities of the Cinema". Participants promote the cooperation between the town halls to improve their positioning as locations for audio-visual productions. The network integrates the efforts of the cities to realize joint actions, in search of promotion (participation in events like cinema festivals or markets) or financing (www.ciudadesdecine.es).

- Network of "Cities of the Music of the UNESCO". It allows sharing of experiences, professional training and technical know-how on a worldwide scale. In addition, it facilitates the reinforcement of local capacities and promotes the diversity of offering of cultural products on the domestic and international markets, the creation of employment and economic and social development (www.unesco.org).

- Network of cities "EUROCITIES". This network was born with the will to take part actively in the construction of the united Europe and, to this end, it acts as an advocate in European institutions and takes part in the decision process in the areas that directly affect the cities (www.eurocities.eu).

- Network of cities "Heritage of Humanity". This is a network that operates in the defense of the historical and cultural heritage of the declared Heritage of Humanity cities. The case of Seville is unusual because not the whole city is declared as Heritage of the Humanity, but three of its big symbols are: the Cathedral, the Fortress and the File of the Indies (www.ciudadespatrimonio.org).

\section{Promotion and commercialization of the tourist product}

Seville projects a clear, consolidated brand image recognized globally and associated with a particular type of positive and vivacious way of life. In addition, it has experience orchestrating the organization and management of big, prestigious cultural, sports and artistic events, recognized not only inside Spanish borders, but also internationally (Plan Estratégico Sevilla 2OIO). 


\section{Cultural activities}

- Flamenco's biennial show: Seville, the capital of flamenco, hosts the most important flamenco festival of the world, known as The Biennial Show. Its principal aim is to teach people how to recognize and better understand this artistic style.

- Opera and symphonic orchestra: These are two of the most relevant cultural events of the Sevillian capital. Of recognized and valued prestige inside and out of our borders, they have been given awards on many occasions.

- Celebration of festivals of national and international relevance, Among them, the following ones stand out:

- Festival of European cinema of Seville,

- International Festival Seville Between Cultures,

- International Festival of Arts of Seville,

- International Festival of Theatre and scenic Arts of Seville,

- International Festival Spoken Word, Movies

- The meeting place for the development of fairs on different subject matter:

- FAC. Fair of Contemporary Art.

- SIMOF. International Fashionable Flamenco Fair.

- SICAB. International Horse Show.

- FMT. Bullfighting World Fair.

- MUNARCO. National Confreres' Crafts Show.

- Major holidays (Holy Week, Fair of April, etc.)

Audio-visual projects - cinema and advertising

One of the more representative lines of action constitutes the announcement of the city that it will begin a campaign to attract audio-visual producers, that is, to create in Seville the material support for full-length films, short films, advertising and other mechanisms that will spread the image of the Andalusian capital.

In this sense, in the year 2000, the Seville Film Office was created, joining the Network of Andalusia Film Commission (AFC), with the intention of promoting the audio-visual sector in the city and of turning Seville into a suitable set to film.

The importance of the audio-visual sector for tourism justifies itself according to the president of the association, "because an image in a movie is equivalent to a costly and extensive advertising campaign and can be a sight for an average of 70 million people" (www.sevillafilmoffice.com).

\section{Combined/Joint Promotion}

Besides the previously mentioned mechanisms, Seville has undertaken new joint actions to try to promote and stimulate its touristic image:

- Program "Multiply the Light". Seville and Huelva join their destinations to offer the tourist an innovative touristic package, which for the first time joins the two Andalusian provinces in order to combat one of the biggest challenges to tourist destinations: seasonal variation. With this, they intend/try to create an image capable of transmitting the attributes, advantages and characteristics of this territory focusing on the complementarity of both provinces: beaches (beaches of Huelva); nature (Doñana's Natural National Park, and Nature Reserve of Sierra de Aracena y Picos de Aroche in Huelva, and Natural Park of Sierra Norte in Seville); golf (I2 golf courses in the provinces of Huelva and Seville) and culture (municipality and province of both cities). 
- The Consortium of Tourism of Seville and LANDALUZ, one of the principal foodprocessing companies of the region, signed an agreement to promote the Andalusian gastronomy in a joint way. With this action, they intend to benefit the projection and commercialization of the gastronomic tourism of the Sevillian capital.

\section{Accomplishment of promotional material}

With the aim of facilitating the compression of the touristic practice, as well as to insist on the promotion of the city on the touristic context, the Town Council constantly undertakes the design and edition of leaflets, tourist guides and tourist catalogues distributed across the offices of tourist information, and other entities linked with the sector.

\section{Quality guarantee}

Quality constitutes one of the big challenges for the city. The advances that have been achieved over the past few years has been significant, but the city of Seville, and in general Spain as a tourist destination, need to become competitive via pricing, an issue that little by little will be changing, always with an eye toward integral quality and with a special attention to the formation in the sector.

Among the emblems that guarantee this touristic quality are the ISO measures or "Q from Quality”, standards that, when achieved, guarantee the prestige, differentiation, reliability and rigor of the certified touristic establishments. These standards have been certified by the Institute for the Tourist Spanish Quality (ICTE) in different establishments linked with the tourist sector.

In Seville, we can estimate a total of twenty-two travel agencies, ten hotel establishments, an office of tourist information and eight restaurants that possess this distinctive badge (ICTE, 2OO9).

\section{Creation of the Tourist Observatory of Seville}

The Town Council has created the Tourist Observatory of the city, which shows a major concern for the statistical sectored analysis related to tourism (Corsotium of Seville).

Studies and investigations are conducted about the demand, epochs of the year, foreign and national markets, types of tourists, housings used (commercial according to types and categories and non-commercial), duration of the stay, systems of commercialization used, and the strata of age and status, in order to canalize the demands for the city's compatible offer.

\section{Capture of new tourist segments.}

The first one of them is the segment of the handicapped persons. They try to promote the city of Seville as a tourist destination totally accessible for the persons with physical disability. Because of this, the Town Council, in collaboration with the Consortium of Tourism of Seville, has the "Guide to Accessible Tourism in Seville. Seville, open to everyone". It gathers establishments (hotels, restaurants, cinemas and theatres), parks and gardens, itineraries, parking reserved to persons with disability who have the European parking card and other types of services accessible and practicable (cruises for the river, tourist bus, buses and eurotaxis), according to the parameters of the Decree of Accessibility of the Junta de Andalucía, being indicated by a specific pictogram those that have information in Braille for blind persons. 
The second one of the major social segments is the homosexual populations. The Consortium of Tourism has overseen during the last years the accomplishment of different activities related to this social group, among which stands out the creation of a "Guide of Gay Tourism" where appears all kinds of facilities orientated to this tourists' sector: from housings, saunas, gay bars and restaurants, as well as exhibitions and other cultural events of interest.

\section{Wealth and well-being in the visits}

A very important issue that also must be present in the construction of the urban tourist model is the evaluation of tourist policies and their influence on translating tourist visits into wealth and well-being for the city's residents in addition to simple quantitative information of received tourists. This way, though most of the actions go to the tourist attractions, it is necessary to analyze intense form of aspects such as loyalty, deseasonality, and the increase of the expense or of the duration of the stay, all of them key for the maximization of the benefits obtained by every visit received.

\section{The tourist visit from other perspectives}

- Tourist Bus "Seville Tour". A global brand that integrates the best operators of panoramic tours around the world under a corporate image that assures the traveller a route of quality and excellence by tourist bus (wwsevillatour.com).

- Cruises "Tower of the Gold". Their aim is to allow the discovery of the Guadalquivir River in different ways: the thousand-year-old river, the romantic river, the river of the conquerors of America, etc. with departures every half hour all year round, allowing the enjoyment of the beautiful views that the river offers (www.crucerostorredeloro.org).

- Panoramic Treadmill, of the British company World Tourist Attractions (WTA). Its slow pace allows the observation of the city from a different perspective, since it is the highest point from which it is possible to see the whole city (www.sevilla5.com).

\section{The Seville Transport: Accessibility and Sustainability}

Any city that wants to obtain a relevant positioning in tourism must adopt a few levels of accessibility according to the needs of the demand. In this context, Seville, one of the big European cities, in which the urban dimension coexists with rural comforts, is today one of the best connected cities in Spain.

Characterized by very varied and efficient accessibility, Seville has turned not only into a point of touristic destination but also into the best port of Andalusia, since it is one of the few Spanish cities communicated efficiently by land, sea, railroad and air.

- Road. The network of highways of regional scope, as well as a renewed system of accesses to the city, with rapid bypasses, connect accurately all the neuralgic points of the city and its surroundings. This way, Seville turns into one of the Spanish cities better communicated by road, linked for highway with all the Andalusian capitals, as well as with Madrid and Portugal. The services are completed with the bus stations of Plaza de Armas and Prado de San Sebastian. 


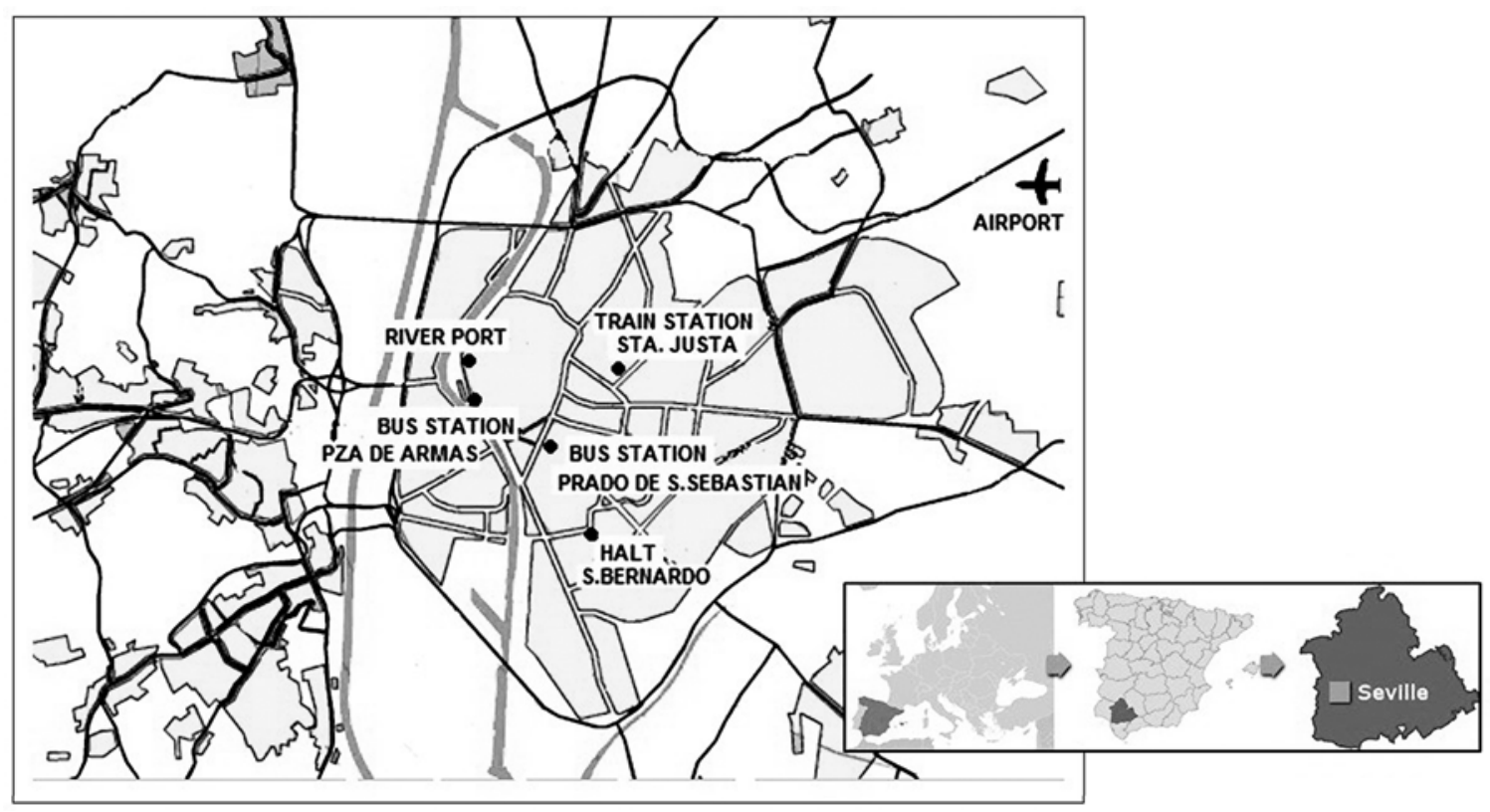

Figure 2 Accessibility to Seville city

Source: Own elaboration

- Railroad. The construction of a new rail network has been fundamental to clear a historical centre previously completely asphyxiated by the dizzy growth of traffic. The railroad station of Santa Justa, constructed by the Sevillian architects Cruz y Ortiz, constitutes an important knot of connections between the Andalusian capital and the rest of the Autonomous Community, Spain and Europe. High Speed's system is formed nowadays by two products: AVE and Talgo 200, which have been placed at the centre of Seville less than two and a half hours from Madrid and only 40 minutes from Cordoba.

- Plane. San Pablo' s new International Airport, the work of Rafael Moneo, is located only IO $\mathrm{km}$ from the downtown. It was specially designed to receive up to eight million passengers per year and it offers regular flights to/from the principal European and Spanish capitals. In the last few years, it has experienced a considerable growth as consequence of the implantation of low-cost airlines, such as Ryanair, Vueling and Air Berlin.

- Ship. The Guadalquivir has a first class port, in addition to being the only interior one in Spain. It supports heavy traffic, either tourist cruises or regular lines of goods. This river receives at the only fluvial port of Spain, placed to 80 kilometres from the Atlantic Ocean and very close to the Mediterranean. The peak of this activity and the enhancement of Pier Delicias further promote the integration of the Port in the City of Seville, which has significantly multiplied its accessibility.

But besides accessibility, the Seville Town Council continues to invest in transport in order to incorporate in the city a real tourism policy of sustainable mobility based on the promotion of non-motorized transport (pedestrian and bicycle) and public transport. 
With the objective of reducing the use of private vehicles, the reduction of the surrounding traffic and the development of a network of bike lanes has been carried out throughout the city by the Historic Centre of pedestrianization. According to the Seville Strategic Plan 2OIO, each time more touristic activity is planned, not only are economic goals to be taken into account, but also ecological and environmental ones.

There are four main projects related to intra-urban sustainable transport that the city has undertaken in recent years:

- Electric Microbus: Opened four years ago, it provides transportation to non-resident or passers-by tourists by means of the environment of pedestrian-friendly streets of downtown Seville. With this, the interest shown by the city of Seville for sustainable transport is shown, opting for a less polluting public transport that cares about the sustainability of the city (www.tussam.es).

- Metrocentro: In search of green transport, the city of Seville in collaboration with the Junta de Andalucía, established an electric train that runs through the centre of the city. With this, a more ecologically effective transport has been achieved, contributing, in turn to the pedestrianization of the historical center (www.tussam.es).

- Blobject. Segway Seville: With the same background of sustainability as in the previous case, the city opted for a new form of tourism and sightseeing. Under the slogan "New ways to make and to see the city" the company offers a unique and fun experience through a Segway, an electric scooter easily controlled by body movements (www.segwayguidetours.com/sevilla).

- Ciclotour: A company from Seville that is active in the sector of leisure and tourism, using quads and bikes. It has the exclusive sales and distribution of the quads for Spain and Portugal. Its motto: "Seville has an exceptional climate with over 300 sunny days per year, with a completely flat terrain, no slopes, perfect for biking effortlessly, quietly and at any age" (www.ciclotour.com/sevilla).

\section{Conclusions}

The Seville Strategic Plan 2OIO has been an important step in addressing the major challenges of tourism in Seville, since all the actions proposed have lead to a breakthrough in terms of shaping the city as a major new tourist destination in the international urban tourism circuit.

Increased competition in this mode is constant, since it is expected that an increasing number of cities will gain a position of importance in urban tourism. That is why it is necessary to continue implementing actions aimed at achieving a competitive and differentiated product, looking for original ways to depart from the standardization of products and services.

Its beauty, its magnificent weather, the superb infrastructure and the available communication network suggest that the city should continue working toward the integration of all its tourism resources. All of these opportunities, if the city knows how to use them, will produce excellent results and therefore allow Seville to assume a privileged place in the great cities of national and international urban tourism. 


\section{References}

Dachary, A., Burne, S. (2004). Globalización y Turismo ¿Dos caras de una misma moneda? Estudios y Perspectivas en Turismo. I3 (3-4).

Holloway, J.Ch. (1994). The Business of Tourism, ed. IV, London: Pitman Publishing.

Iordache, C. and Cebuc, I. (2OO9). The influence of juridical regulations upon tourist town planning. Theoretical and Empirical Researches in Urban Management, I(IO), 86-92.

Marchena, M.; Repiso, F. (I999). Turismo Cultural: El caso de Sevilla. Cuadernos de Turismo. $\mathrm{N}^{0} 4 ., 33-5 \mathrm{O}$.

Popescu R. I. and Corbos R. A. (2OIO). The role of Urban Tourism in the strategical development of Brasov Area. Theoretical and Empirical Researches in Urban Management Number 7(I6) / August. 2010

Prados Pérez, E. (200I). Turismo cultural: un segmento turístico en expansión. En Congreso virtual de Turismo Cultural. www.naya.org.ar

Romero Moragas (2004). Patrimonio, Turismo y Ciudad. Boletín del Instituto Andaluz de Patrimonio. $\mathrm{N}^{0}$ 9., I6-2I

Stanciulescu, G. C. (2009). The role of urban marketing in the local economic development. Theoretical and Empirical Researches in Urban Management, I(IO), II4-I35

Tresserras, J. (2005). Patrimonio y Turismo: Una Alianza Estratégica. En Patrimonio, turismo y Desarrollo. Tema 4, Módulo A3, Curso de postgrados Turismo Culatural. Barcelona. Universidad de Barcelona.

Troitiño Vinuesa, M.A. et al. (I995). Turismo, accesibilidad y medio ambiente en ciudades históricas. Madrid: Ministerio de Obras Publicas, transporte y medio Ambiente, 1995. Informe inédito. Tres volúmenes.

World Tourism Organization (1994). National and Regional Tourism Planning Methodology and Cases, London: Routledge.

World Tourism Organization, Earth Council (1997). Agenda 2I for the travel and tourism industry.

European Commission (1998). Sustainable urban development in the European Union: a framework for action, Communication from the Commission, October 28.

Conference on "Tourism and the City: The challenge of sustainability". November, I999., Madrid.

Comisión Europea (2000). Por un turismo urbano de calidad. Gestión integrada de la calidad de los destinos turísticos urbanos.

Plan estratégico Sevilla 2010.

Ayuntamietno de Sevilla (2006). Informe Económico y Presupuestos Generales. Memoria 2006.

\section{Websites}

Town Council of Seville: www.sevilla.org

Consortium of Seville. www.turismodesevilla.org

European Union (tourism): http://ec.europa.eu/enterprise/sectors/tourism

World Tourism Organization: www.unwto.org

Institute for the Tourist Spanish Quality: www.icte.org

Network of cities "Spain Convention Bureau": www.scb.es

Network of "cathedral cities": www.ciudadescatedralicias.org

Network of "Cities of the Route of the Silver": www.rutadelaplata.com 
Network of "cities AVE": www.redciudadesave.es

Network of "cities of the Cinema": www.ciudadesdecine.es

Network of "Cities of the Music of the UNESCO": www.unesco.org

Network of cities "EUROCITIES": www.eurocities.eu

Network of cities "Heritage of Humanity": www.ciudadespatrimonio.org

Urban Transportation in Seville: www.tussam.es

Blobject. Segway Seville: www.segwayguidetours.com/sevilla

Ciclotour Seville: www.ciclotour.com/sevilla

Port of Seville: www.apsevilla.org

Cruises “Tower of the Gold”: www.crucerostorredeloro.org

Exhibitions and Congresses Palace of Seville: www.fibes.es

Gastronomic tourism in Seville: www.visitingsevilla.com/turismgastronomico

Tourism of golf in Seville: www.sevillagolf.com

Sevilla Card: www.sevillacard.es

Channel for tourist information of Seville: www.turismosevilla.tv

Seville Film Office: www.sevillafilmoffice.com

Panoramic Treadmill: www.sevilla5.com 